\title{
The soil-plant-feed transport of selenium and other essential micronutrients in diet of sport and recreational horses at two different locations
}

\author{
N. Žáková, J. Száková1, J. Tremlová, J. Najmanová and P. Tlustoš \\ Czech University of Life Science Prague, \\ Faculty of Agrobiology, Food and Natural Resources, Department of Agro-Environmental Chemistry and Plant Nutrition \\ Kamýcká 129, 16521 Prague-Suchdol, Czech Republic
}

KEY WORDS: horse, soil, selenium, deficiency, essential elements, nutrition

Received: 22 December 2014

Revised: $\quad 18$ August 2016

Accepted: 10 December 2016
${ }^{1}$ Corresponding author: e-mail: szakova@af.czu.cz

\begin{abstract}
In the Czech Republic, low soil selenium (Se) contents followed by insufficient soil-plant-animal transport of this element have been previously reported. Therefore, the attention of animal nutrition experts should be focused more intensively on the Se status in grazing animals. The experiment was carried out on 42 horses from two locations, $A$ and $B$ ( 21 animals per group), where the animals are used for sport or recreational purposes, respectively. The Se contents in soil, selected plants, individual components of the diet and animal whole blood were determined. The soil Se contents varying between 0.233 and $0.507 \mathrm{mg} \cdot \mathrm{kg}^{-1}$, confirmed low Se contents in the Czech soils. Similarly, the Se contents in plants were low and did not exceed $0.07 \mathrm{mg} \cdot \mathrm{kg}^{-1}$ of dry matter (result of low Se mobility in the investigated soils), whereas the levels of other essential micronutrients, such as copper, iron, manganese and zinc, occurred in the sufficient concentrations. The Se contents in the whole blood of animals varied between 0.044 and $0.215 \mathrm{mg} \cdot \mathrm{I}^{-1}$ and were comparable with the results of many other similar studies conducted across the Europe. The adequate Se status in animals can be strongly related to the high Se contents in complementary feedstuffs such as pellets and muesli, whereas feeding animal diets based only on roughage and grain produced at the investigated farms could be Se deficient. Therefore, the supplementation of horse diet with Se is recommended in the Czech Republic.
\end{abstract}

\section{Introduction}

Selenium (Se) is a trace mineral that is essential for living organisms but required only in small amounts. Se is incorporated into proteins to develop selenoproteins, some of which are important antioxidant enzymes. The antioxidant properties of selenoproteins help to prevent cellular damage from free radicals. Rayman (2008) assumed that the additional health benefits of Se, such as improved immune system and reduced cancer risk, require higher than recommended daily intakes. The content of Se in food depends on the Se content in the soil where plants are grown or animals are kept. Bitterli et al. (2010) reviewed that common soil Se concentrations range between 0.1 and $5 \mathrm{mg} \cdot \mathrm{Se} \mathrm{kg}^{-1}$ (average around $0.4 \mathrm{mg} \cdot \mathrm{Se} \mathrm{kg}^{-1}$ of soil dry matter). Many regions worldwide are characterized by low amounts of Se in the soil, 
resulting in deficient concentrations of Se in feedstuffs (Swecker et al., 1991; Masters et al., 1999). Monitoring of Se status and its intake by horses was conducted by Wichert et al. (2002) in Bavaria (Germany), where only $25 \%$ of horses were characterized by higher Se intake than recommended $-2.5 \mu \mathrm{g}$ per kg of body weight, whereas $52 \%$ consumed less than $50 \%$ Se supply. In contrast, $85 \%$ of animals obtained the recommended copper supply. Moreover, the Se plasma levels in many cases were lower than the reference levels. Similarly, Ludvíková et al. (2005a) identified an insufficient Se level in $42 \%$ of 136 horses from different farms in the Czech Republic. Within Europe are very large differences in the Se supply - countries closer to the ocean provide a better Se supply than those in Central Europe (Müller et al., 2012).

The changes in nutrient contents in horses can be affected also by oxidative stress and the health status of the animals. Youssef et al. (2012) observed a significant decrease of serum $\mathrm{Se}, \mathrm{Cu}, \mathrm{Zn}$ and $\mathrm{Fe}$ levels in draft horses with lower airway disease in comparison with healthy ones, whereas the $\mathrm{Cu}: \mathrm{Zn}$ ratio and $\mathrm{Mn}$ were increased. However, no effect of Se supplementation to horse diet on utilization of other micronutrients by the animal organism was observed (Gordon et al., 2013). The serum element contents were: $\mathrm{Se} 0.008-0.237 \mathrm{mg} \cdot 1^{-1}, \mathrm{Cu} 0.108$ $2.80 \mathrm{mg} \cdot 1^{-1}$, Zn 0.033-0.582 mg $\cdot 1^{-1}$, Mn 0.030 $0.203 \mathrm{mg} \cdot 1^{-1}$ and Fe $0.904-2.88 \mathrm{mg} \cdot 1^{-1}$.

Streeter et al. (2012) proved significant associations between white muscle disease and Se deficiency in the blood of 30-day-old foals. However, there was no relationship between Se and myopathy in the group of horses aging $>2$ years, and no relationships were found between sex, breed or size categorizations in this group. Additionally, Ludvíková et al. (2005b) reported significantly lower Se content in the blood of horses with myopathy. In 1978 the activity of glutathione peroxidase (GSH-Px), a Se containing enzyme, was measured in the blood of horses as an indicator of Se status (Caple et al., 1978). The range of GSH-Px activities indicated that Se intake by horses varied widely between locations. Brummer et al. (2013) observed a higher increase of GSH-Px activity in the blood of Se-supplemented horses after preliminary depletion of dietary Se in comparison with the animals regularly fed the Se-adequate diet, suggesting a good potential response of animals in the Sedeficient areas on the supplementation.

Yur et al. (2008) investigated the effect of intensive exercise on the element levels in horse serum. Among the macro- and micronutrients, only the $\mathrm{Cu}$ level and the $\mathrm{Cu}: \mathrm{Zn}$ ratio was significantly increased, but the concentrations of $\mathrm{Ca}, \mathrm{K}, \mathrm{Fe}$ and $\mathrm{Mg}$ remained unchanged in intensively exercised horses. Similarly, in serum the increased values of $\mathrm{Cu}$ after training, with a simultaneous significant decrease of $\mathrm{Zn}$ and $\mathrm{Mn}$ levels, were observed by Minini et al. (2013). Yur et al. (2008) tested the effect of $\mathrm{Se}$ on nutrient levels in horse serum as affected by exercise. In horses treated with Se, the $\mathrm{Ca}$ and $\mathrm{K}$ levels decreased to levels lower than those of untreated controls before and after exercise. These findings indicate interrelationships between Se and other essential elements in horses. The serum contents varied: $0.052-0.063 \mathrm{mg} \cdot \mathrm{l}^{-1}$ for $\mathrm{Zn}$, $0.178-0.274 \mathrm{mg} \cdot 1^{-1}$ for $\mathrm{Fe}$, and $0.073-0.191 \mathrm{mg} \cdot 1^{-1}$ for $\mathrm{Cu}$. The whole blood Se contents in endurance horses tended to increase from $0.19 \mathrm{mg} \cdot 1^{-1}$ in preride phase to $0.21 \mathrm{mg} \cdot 1^{-1}$ in the post-ride phase (Haggett et al., 2010). The effect of age on Se concentrations in sport horses was observed by de Moffarts et al. (2005), who measured such Se plasma contents as $0.104 \mathrm{mg} \cdot 1^{-1}$ and $0.117 \mathrm{mg} \cdot 1^{-1}$ in twoyear-old and three-year-old animals, respectively. Higher Se serum levels (as well as the levels of other micronutrients such as $\mathrm{Mn}, \mathrm{Fe}, \mathrm{Zn}$ and $\mathrm{Cu}$ ) were observed in pregnant mares (Ali et al., 2013) in comparison with others, indicating the importance of optimum nutrient status for fertility of the animals.

Thorson et al. (2010) investigated the effect of Se supplementation (as selenomethionine, SeMet) on mares, but did not observed this effect on foaling variables and foal body weight as well as on colostral fat, protein, milk, urea $\mathrm{N}$ or somatic cell count. However, Se supplementation $(0.3 \mathrm{mg}$ of SeMet per $\mathrm{kg}$ of the diet dry matter) resulted in decreased placental cell size in mares, suggesting the potential effect of Se on the organism. Concerning the Se uptake, a source of Se did not affect Se concentrations in maternal plasma, red blood cells, colostrum or milk, but Se contents in these matrices were higher in the Se-supplemented animals (Karren et al., 2010; Thorson et al., 2010). However, in one-month-old foals from mares fed diet with organic Se higher red blood cell Se concentration than in foals from mares fed diet with inorganic Se was observed (Montgomery et al., 2012). The effect of Se supplementation on the production of colostral immunoglobulins (IgG) by beef cows was investigated by Swecker et al. (1995), who found that Se-supplemented cows had higher colostral IgG concentration in comparison with the Se-deficient ones. Similarly, the effect of Se supplementation on the oxidative status of mares was observed by 
Calamari et al. (2010), who described an improvement in the preventive antioxidant systems of horses fed SeMet-supplemented diet. Differences in the response of the horse organism on Se source were observed by Richardson et al. (2006) and Calamari et al. (2009). Richardson et al. (2006) found that the supplementation of SeMet resulted in higher Se plasma concentrations after 28 days of exposure, while after 56 days no differences between inorganic and organic Se sources were reported. However, Se toxicosis caused by too high Se contents in the mineral supplements can occur (Detlef et al., 1995). Coenen et al. (1998) described the effect of the overdosed supplement (up to $1860 \mathrm{mg} \cdot \mathrm{kg}^{-1}$ ), where the Se intake reached $153 \mathrm{mg} \cdot$ day $^{-1}$ (for non-supplemented animals, the average Se intake was $2.1 \mathrm{mg} \cdot$ day $^{-1}$ ) and plasma Se reached $0.307 \mathrm{mg} \cdot 1^{-1}$.

The impact of pasture $\mathrm{Se}$ contents presents a dominant factor affecting the Se intake, and subsequently the Se status of grazing animals such as horses. In our investigation, the Se status of two groups of horses (sport and recreational) was studied as affected by the pasture Se contents to assess: 1. the ratio of dietary Se intake represented by the pasture at individual locations, 2. the impact of Se content in pasture plants on Se levels in the whole blood of the animals, and 3. the potential influence of insufficient Se intake on animal health at the investigated locations.

\section{Material and methods}

\section{Locations, animals and sampling}

The experiment was carried out on 42 horses, $60 \%$ males, $40 \%$ females, from two locations. In location A were 21 recreational horses (Czech Warmblood, Slovak Warmblood and Akhal-teke; aged 2-19 years) stabled in Chrastava near Liberec (North Bohemia, Czech Republic, N 5049.84913', E 1458.67180') used only for recreational purposes about $1 \mathrm{~h}$ per day. In the second group (location B) were 21 sport horses from a training centre in Bošovice (South Bohemia, Czech Republic, $\left.\mathrm{N} 49^{\circ} 20.71795^{\prime}, \mathrm{E} \mathrm{14}{ }^{\circ} 5.29675^{\prime}\right)$. All of these animals were thoroughbred, aged 2-10 years. The young horses were intensively trained for racing (about $2 \mathrm{~h}$ per day), horses aging 4-5 years were exercised for flat racing and older ones for steeplechase. The animals were regularly pastured and/or fed roughage originating from both locations.

Blood samples were collected from vena jugularis and kept in test tubes with anticoagulant -
$\mathrm{K}_{2}$ EDTA. The blood samples were frozen at $-15^{\circ} \mathrm{C}$ until further analysis. The representative samples of roughage, grain and compound feed, as well as representative samples of individual plant species growing at the pasture were collected at both locations $\left(1 \mathrm{~m}^{2}\right.$ squares were delineated where the number of individual plant species was identified, and representative sample of aboveground biomass of each species was collected). The plant samples were dried at $60{ }^{\circ} \mathrm{C}$ to a constant mass and then ground into a fine powder using a laboratory mill. Two laboratory soil samples were collected from each sampling point (A1 and A2 from the location $\mathrm{A}$, and $\mathrm{B} 1$ and $\mathrm{B} 2$ from the location B) from a depth of 0-25 cm, and each sample represented an average of three sub-samples taken from each sampling square. At both locations, the soil type was Luvisol. Soil samples for the determination of total and mobile concentrations of elements were air dried at $20^{\circ} \mathrm{C}$, ground in a mortar and passed through a $2 \mathrm{~mm}$ plastic sieve. All the blood, plant and soil samples were taken in July.

\section{Analytical methods}

The pseudototal concentrations of elements in the soils were determined in the digests obtained by the following decomposition procedure. Aliquots $(\sim 0.5 \mathrm{~g})$ of air-dried soil samples were decomposed in a digestion vessel with $10 \mathrm{ml}$ of Aqua Regia (i.e. nitric and hydrochloric acid mixture, 1:3). The mixture was heated in the Ethos 1 (MLS GmbH, Leutkirch im Allgäu, Germany) microwave-assisted wet digestion system for $33 \mathrm{~min}$ at $210^{\circ} \mathrm{C}$. After cooling, the digest was quantitatively transferred into a $25 \mathrm{ml}$ glass tube, topped up by deionized water and kept at laboratory temperature until measurements were taken. A certified reference material RM 7003 Silty Clay Loam (Analytika, Prague, Czech Republic) was applied for the quality assurance of analytical data. For determination of element contents in aboveground biomass of plants, diet components and whole blood of horses, an aliquot ( $\sim 500 \mathrm{mg}$ of dry matter of the solid matter or $500 \mu 1$ of whole blood) was weighed in a digestion vessel. Concentrated nitric acid $(8.0 \mathrm{ml})$ (Analytika Ltd., Prague, Czech Republic) and 30\% $\mathrm{H}_{2} \mathrm{O}_{2}(2.0 \mathrm{ml})$ (Analytika Ltd., Czech Republic) were added. The mixture was heated in the Ethos 1 (MLS $\mathrm{GmbH}$, Leutkirch im Allgäu, Germany) microwaveassisted wet digestion system for $30 \mathrm{~min}$ at $220^{\circ} \mathrm{C}$.

The soil $\mathrm{pH}$ value was determined in $0.01 \mathrm{M}$ $\mathrm{CaCl}_{2}$ extract at a range of 1:10 (w/v; Novozamsky et al., 1993). For the determination of mobile fractions of elements in soils, extraction with a $0.11 \mathrm{~mol} \cdot 1^{-1}$ solution of $\mathrm{CH}_{3} \mathrm{COOH}$ at ratio 1:20 
(w/v) for $16 \mathrm{~h}$ (Quevauviller et al., 1993) was applied. Each extraction was carried out in three replicates. For the centrifugation of extracts, a Hettich Universal 30 RF (Hettich, Tuttlingen, Germany) device was used. The reaction mixture was centrifuged at $3000 \mathrm{rpm}$ (i.e. $460 \mathrm{~g}$ ) for $10 \mathrm{~min}$ at the end of each extraction procedure, and the supernatants were kept at $6{ }^{\circ} \mathrm{C}$ prior to measurements.

Inductively coupled plasma atomic emission spectrometry (ICP-OES, Varian, VistaPro, Mulgrave, Australia) and inductively coupled plasma mass spectrometry (ICP-MS, Agilent 7700x, Agilent Technologies Inc., Santa Clara, CA, USA) equipped with an auto-sampler ASX-500, a three channel peristaltic pump and a MicroMist nebulizer were used for the determination of elements in soil extracts, plant and blood samples.

The analytical data were processed using Statistica ver. $10 \mathrm{Cz}$ statistical software (StatSoft Inc., Tulsa, OK, USA). Correlation analysis was used for the assessment of relationships between variables, whereas Pearson's correlation coefficients were applied for the data characterized by the normal data distribution. Non-parametric Spearman's correlation was used in the remaining cases (Meloun and Militký, 2004).

\section{Results}

\section{Se contents in the soil, roughage and whole diet}

The pseudototal contents of selected elements and the element portions (extractable with $0.11 \mathrm{~mol} \cdot 1^{-1}$ $\mathrm{CH}_{3} \mathrm{COOH}$ ) are summarized in Tables 1 and 2.
The element contents in the selected plant species (Table 3) reflect both total element contents and their mobility. $\mathrm{Cu}$ and $\mathrm{Zn}$ contents were comparable among the analysed species, whereas $\mathrm{Fe}$ and especially $\mathrm{Mn}$ contents showed high variability among species growing at the same location. Among plant species, Trifolium repens and Artemisia vulgaris tended to have higher $\mathrm{Cu}, \mathrm{Fe}, \mathrm{Mn}$ and $\mathrm{Zn}$ uptake, but not unambiguously.

Although the roughage represents a dominant portion of the diet (Table 4), other components differ according to the individual locations and also differ between the recreational horses at location A and the sport horses at location B. Fe and Zn daily intake was comparable for both locations, whereas $\mathrm{Mn}$ and $\mathrm{Cu}$ daily intake was lower in the case of sport horses. This situation resulted from lower $\mathrm{Cu}$ content in pellets used for sport horses feeding and the higher variability of $\mathrm{Mn}$ contents in plant biomass at location B. However, according to Davies (2009), the Fe, Mn and Zn daily intakes were sufficient for optimum horse nutrition, but $\mathrm{Cu}$ contents were under the recommended optimum.

\section{Se and other micronutrient status of the animals}

No differences between blood element contents between locations A and B, except for Se, were observed (Table 5). The higher average Se concentration at location $\mathrm{B}\left(0.171 \pm 0.027 \mathrm{mg} \cdot \mathrm{l}^{-1}\right)$ than at location A $\left(0.097 \pm 0.034 \mathrm{mg} \cdot \mathrm{1}^{-1}\right)$ clearly reflects the higher daily Se uptake at this location. Opposite findings were published by Ludvíková et al. (2005b), who observed that the average Se blood

Table 1. Pseudototal concentrations of selenium and other investigated elements in soils

\begin{tabular}{|c|c|c|c|c|c|c|}
\hline \multirow{2}{*}{ Sample } & \multicolumn{6}{|c|}{ Pseudototal concentrations of elements in soils, $\mathrm{mg} \cdot \mathrm{kg}^{-1}$} \\
\hline & Se & As & $\mathrm{Cd}$ & $\mathrm{Cu}$ & $\mathrm{Pb}$ & $\mathrm{Zn}$ \\
\hline$\overline{\mathrm{A} 1}$ & $0.470 \pm 0.030$ & $11.18 \pm 0.78$ & $0.186 \pm 0.01$ & $6.78 \pm 1.25$ & $21.4 \pm 0.36$ & $41.9 \pm 9.65$ \\
\hline A2 & $0.507 \pm 0.048$ & $16.08 \pm 1.78$ & $0.324 \pm 0.11$ & $8.04 \pm 0.47$ & $26.7 \pm 0.97$ & $61.3 \pm 0.86$ \\
\hline B1 & $0.233 \pm 0.056$ & $5.48 \pm 0.89$ & $0.108 \pm 0.02$ & $10.23 \pm 0.02$ & $14.1 \pm 4.44$ & $47.0 \pm 5.50$ \\
\hline B2 & $0.404 \pm 0.025$ & $8.37 \pm 0.11$ & $0.264 \pm 0.01$ & $12.44 \pm 0.25$ & $18.0 \pm 0.12$ & $67.0 \pm 2.39$ \\
\hline
\end{tabular}

data are presented as mean \pm standard deviation; sample labels indicate the individual sampling points at investigated locations; $n=3$

Table 2. Mobile portions of selenium and other investigated elements in soils extractable with $0.11 \mathrm{~mol} \cdot l^{-1} \mathrm{CH}_{3} \mathrm{COOH}$

\begin{tabular}{|c|c|c|c|c|c|c|}
\hline \multirow{2}{*}{ Sample } & \multicolumn{6}{|c|}{ Mobile portions of elements in soils, $\mathrm{mg} \cdot \mathrm{kg}^{-1}$} \\
\hline & $\mathrm{Se}$ & As & $\mathrm{Cd}$ & $\mathrm{Cu}$ & $\mathrm{Pb}$ & $\mathrm{Zn}$ \\
\hline A1 & $<$ d... ${ }^{1}$ & $0.258 \pm 0.078$ & $0.067 \pm 0.002$ & $0.078 \pm 0.016$ & $0.331 \pm 0.022$ & $1.68 \pm 0.01$ \\
\hline A2 & $<$ d.I. & $0.421 \pm 0.000$ & $0.104 \pm 0.001$ & $0.075 \pm 0.015$ & $0.296 \pm 0.042$ & $7.92 \pm 1.01$ \\
\hline B1 & $<$ d.I. & $0.151 \pm 0.024$ & $0.042 \pm 0.000$ & $0.068 \pm 0.006$ & $0.264 \pm 0.070$ & $3.20 \pm 0.15$ \\
\hline B2 & $<$ d.I. & $0.144 \pm 0.017$ & $0.061 \pm 0.000$ & $0.072 \pm 0.004$ & $0.420 \pm 0.143$ & $1.95 \pm 0.05$ \\
\hline
\end{tabular}

$1<$ d.I. - data under detection limit; data are presented as mean \pm standard deviation; sample labels indicate individual sampling points at investigated locations; $n=3$ 
Table 3. Contents of selenium and other investigated elements in individual plant species

\begin{tabular}{|c|c|c|c|c|c|}
\hline \multirow{2}{*}{ Plant species } & \multicolumn{5}{|c|}{ Content of elements, $\mathrm{mg} \cdot \mathrm{kg}^{-1}$} \\
\hline & $\mathrm{Se}$ & $\mathrm{Cu}$ & $\mathrm{Fe}$ & $\mathrm{Mn}$ & $\mathrm{Zn}$ \\
\hline \multicolumn{6}{|l|}{ Location A } \\
\hline Cirsium arvense (L.) Scop. & $0.046 \pm 0.003$ & $12.7 \pm 0.6$ & $284 \pm 34$ & $34.5 \pm 0.1$ & $28.1 \pm 0.6$ \\
\hline Dactylis glomerata L. & $0.030 \pm 0.004$ & $4.85 \pm 0.23$ & $67.1 \pm 1.7$ & $90.5 \pm 2.7$ & $31.0 \pm 2.5$ \\
\hline Galium mollugo (L.) Scop. & $0.067 \pm 0.002$ & $5.15 \pm 0.62$ & $55.3 \pm 13.3$ & $29.8 \pm 4.9$ & $27.9 \pm 1.5$ \\
\hline Phleum pratense L. & $0.022 \pm 0.004$ & $5.31 \pm 0.16$ & $57.9 \pm 1.6$ & $53.6 \pm 2.6$ & $20.7 \pm 1.3$ \\
\hline Trifolium repens $\mathrm{L}$ & $0.015 \pm 0.001$ & $5.33 \pm 0.12$ & $220 \pm 13$ & $133 \pm 7$ & $16.0 \pm 1.1$ \\
\hline \multicolumn{6}{|l|}{ Location B } \\
\hline Achillea millefolium $\mathrm{L}$. & $0.009 \pm 0.000$ & $3.99 \pm 1.32$ & $38.5 \pm 7.9$ & $102 \pm 8$ & $17.6 \pm 5.0$ \\
\hline Artemisia vulgaris $\mathrm{L}$. & $0.016 \pm 0.004$ & $8.10 \pm 1.07$ & $70.3 \pm 6.1$ & $63.9 \pm 7.5$ & $22.7 \pm 2.2$ \\
\hline Dactylis glomerata L. & $<$ d...$^{1}$ & $4.11 \pm 0.90$ & $38.9 \pm 7.9$ & $96.1 \pm 11.8$ & $17.0 \pm 4.1$ \\
\hline Festuca pratensis Huds. & $<$ d.l. & $2.21 \pm 0.01$ & $28.1 \pm 0.4$ & $46.8 \pm 1.1$ & $10.0 \pm 0.8$ \\
\hline Phleum pratense L. & $<$ d.l. & $1.81 \pm 0.10$ & $30.2 \pm 1.6$ & $38.1 \pm 0.1$ & $14.4 \pm 0.6$ \\
\hline Trifolium pratense L. & $0.013 \pm 0.001$ & $4.29 \pm 0.81$ & $43.3 \pm 14.4$ & $51.9 \pm 10.7$ & $18.1 \pm 3.6$ \\
\hline Trifolium repens $\mathrm{L}$ & $<$ d.I. & $2.76 \pm 0.12$ & $36.6 \pm 4.9$ & $58.4 \pm 2.8$ & $12.5 \pm 0.5$ \\
\hline
\end{tabular}

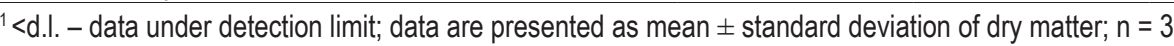

Table 4. Diet components and daily element uptake according to individual locations

\begin{tabular}{|c|c|c|c|c|c|c|c|c|c|c|c|}
\hline \multirow{3}{*}{ Component } & \multirow{3}{*}{$\begin{array}{l}\text { Daily } \\
\text { dose, } \\
\mathrm{kg}\end{array}$} & \multicolumn{10}{|c|}{ Daily elements uptake } \\
\hline & & \multicolumn{2}{|c|}{$\mathrm{Se}$} & \multicolumn{2}{|l|}{$\mathrm{Cu}$} & \multicolumn{2}{|l|}{$\mathrm{Fe}$} & \multicolumn{2}{|l|}{$\mathrm{Mn}$} & \multicolumn{2}{|l|}{$\mathrm{Zn}$} \\
\hline & & $\mathrm{mg} \cdot \mathrm{kg}^{-1}$ & $\mathrm{mg} \cdot$ day $^{-1 a}$ & $\mathrm{mg} \cdot \mathrm{kg}^{-1}$ & $\mathrm{mg} \cdot$ day $^{-1 a}$ & $\mathrm{mg} \cdot \mathrm{kg}^{-1}$ & $\mathrm{mg} \cdot$ day $^{-1 a}$ & $\mathrm{mg} \cdot \mathrm{kg}^{-1}$ & $\mathrm{mg} \cdot$ day $^{-1 a}$ & $\mathrm{mg} \cdot \mathrm{kg}^{-1}$ & $\mathrm{mg} \cdot$ day $^{-1 a}$ \\
\hline \multicolumn{12}{|l|}{ Location A } \\
\hline silage & 5 & 0.033 & 0.082 & 1.20 & 3.00 & 51.2 & 128 & 81.8 & 205 & 7.33 & 18.4 \\
\hline hay & 6 & 0.028 & 0.148 & 3.02 & 15.9 & 95.6 & 505 & 176 & 1054 & 13.8 & 82.8 \\
\hline oat grain & 3 & 0.010 & 0.030 & 2.77 & 8.31 & 59.7 & 179 & 49.1 & 147 & 24.4 & 73.2 \\
\hline pellets & 2 & 0.198 & 0.396 & 11.6 & 23.1 & 355 & 708 & 85 & 170 & 84.7 & 169 \\
\hline fresh fodder & 6 & 0.010 & 0.012 & 3.82 & 22.9 & 24.9 & 149 & 12 & 71.9 & 0.96 & 5.76 \\
\hline total & 22 & $0.048^{b}$ & 0.668 & $5.24^{b}$ & 73.2 & $119^{b}$ & 1669 & $118^{b}$ & 1648 & $25.0^{b}$ & 349 \\
\hline \multicolumn{12}{|l|}{ Location B } \\
\hline hay & 10 & 0.021 & 0.185 & 2.73 & 24.0 & 55.7 & 490 & 38.0 & 334 & 16.1 & 143 \\
\hline oat grain & 4 & 0.011 & 0.044 & 2.22 & 8.88 & 48.1 & 192 & 25.7 & 103 & 19.9 & 79.4 \\
\hline pellets & 0.5 & 0.082 & 0.041 & 3.77 & 1.89 & 350 & 175 & 40.3 & 20.1 & 27.5 & 13.8 \\
\hline muesli & 1.5 & 0.465 & 0.698 & 22.5 & 33.8 & 378 & 567 & 88.2 & 132 & 141 & 212 \\
\hline total & 16 & $0.065^{b}$ & 0.968 & $2.35^{b}$ & 68.6 & $96.2^{b}$ & 1424 & $39.8^{b}$ & 590 & $30.3^{b}$ & 449 \\
\hline
\end{tabular}

a - element concentrations in individual diet components are expressed in dry matter; daily intake was recalculated to real fresh mass of these components; the 'total' was calculated as weighed mean, where the percentage of the individual components in the whole diet was taken into account, thus the value do not represent the sum of the data within the column; ${ }^{b}$ - data expressed as weighed mean of element contents in whole diet dry matter

Table 5. Main statistical characteristics of total concentrations of investigated elements in whole blood of horses

\begin{tabular}{llllll}
\hline $\begin{array}{l}\text { Statistical } \\
\text { characteristics }\end{array}$ & \multicolumn{6}{l}{ Elements concentration in the animal whole blood, $\mathrm{mg} \cdot \mathrm{l}^{-1}$} & & $\mathrm{Mn}$ & $\mathrm{Zn}$ \\
\cline { 2 - 6 } $\begin{array}{l}\text { Location A } \\
\text { minimum }\end{array}$ & $\mathrm{Se}$ & $\mathrm{Cu}$ & $\mathrm{Fe}$ & & \\
maximum & 0.044 & 0.441 & 265 & 0.016 & 1.61 \\
average & 0.215 & 0.739 & 413 & 0.188 & 3.24 \\
SD $^{\mathrm{a}}$ & 0.045 & 0.591 & 334 & 0.063 & 2.20 \\
median & 0.094 & 0.084 & 32 & 0.053 & 0.407 \\
MAD & 0.032 & 0.592 & 339 & 0.035 & 2.10 \\
Location B & & 0.052 & 19 & 0.013 & 0.321 \\
minimum & 0.125 & & & & 1.59 \\
maximum & 0.209 & 0.319 & 269 & 0.019 & 3.02 \\
average & 0.164 & 1.12 & 442 & 0.098 & 2.26 \\
SD & 0.027 & 0.610 & 362 & 0.054 & 0.420 \\
median & 0.171 & 0.163 & 43 & 0.025 & 2.19 \\
MAD & 0.027 & 0.584 & 362 & 0.051 & 0.250 \\
\hline
\end{tabular}

${ }^{a}$ - standard deviation; ${ }^{b}$ - median of absolute deviations 

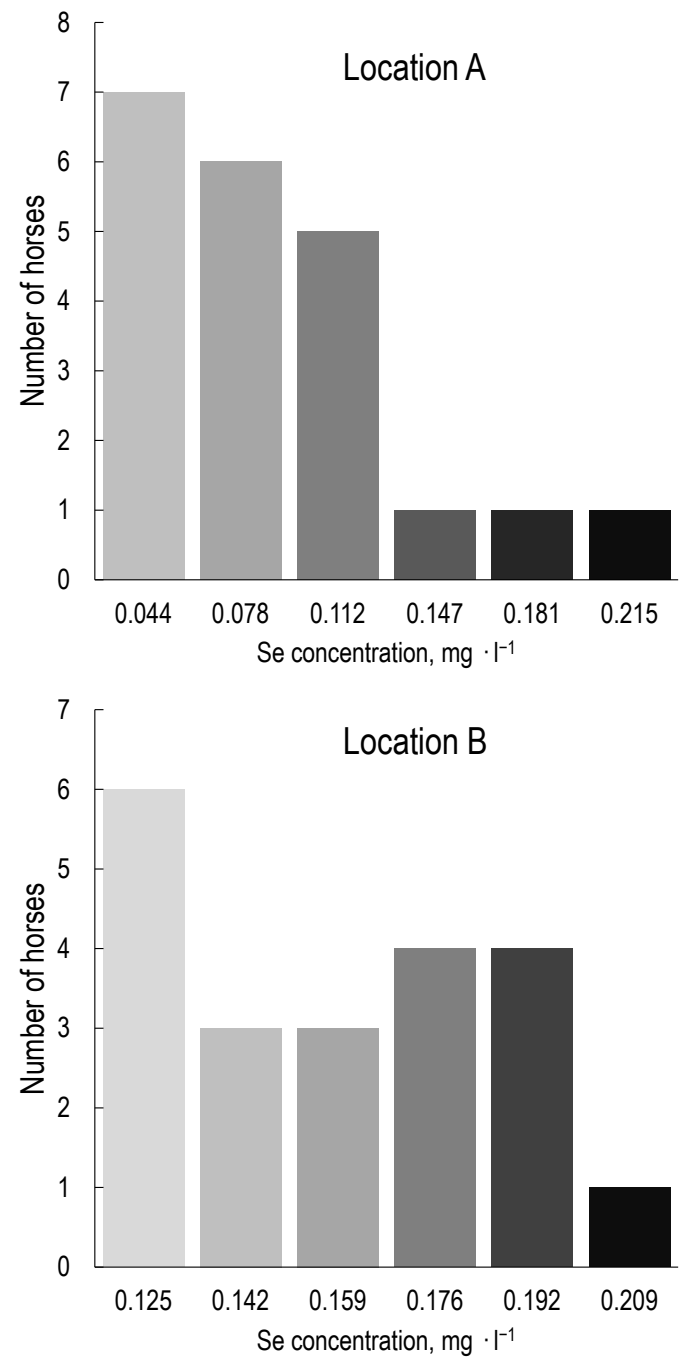

Figure 1. Frequency histograms of selenium concentration levels in animal whole blood according to individual locations

contents were $0.089 \mathrm{mg} \cdot 1^{-1}$ in South Bohemia and $0.175 \mathrm{mg} \cdot 1^{-1}$ in North Bohemia. This supports the statement about the predominant role of the Se content in the diet at the individual locations, including potential supplementation of the diet. Higher variability of the results (Figure 1) was observed in the case of location A, where the Se levels varied between 0.044 and $0.215 \mathrm{mg} \cdot 1^{-1}$, and the range can be accounted to several apparently higher levels occurring at this location. Lower heterogeneity of Se concentrations was then found at location B and ranged between 0.125 and $0.209 \mathrm{mg} \cdot 1^{-1}$.

\section{Discussion}

Se contents in the soil, roughage and whole diet. The maximum permissible limits of elements in soils in the Czech Republic are given by public notice (Czech Ministry of the Environment, 1994).
According to this notice, the pseudototal element concentrations are set as 30,1.0, 100, 140 and $200 \mathrm{mg} \cdot \mathrm{kg}^{-1}$ for $\mathrm{As}, \mathrm{Cd}, \mathrm{Cu}, \mathrm{Pb}$ and $\mathrm{Zn}$, respectively. Hence, the measured contents did not exceed these levels for all of samples and measured elements. The Se contents in soil are not regulated by the Czech public notice (Czech Ministry of the Environment, 1994), but Bitterli et al. (2010) reviewed the obvious Se contents in soils in the range between 0.2 and $0.5 \mathrm{mg} \cdot \mathrm{kg}^{-1}$ with mean value $0.4 \mathrm{mg} \cdot \mathrm{kg}^{-1}$. Northern Europe is cited as a location characterized by low Se contents in the soil. Gupta and Gupta (2000) determined in a set of Scandinavian soils that Se contents varied between 0.42 and $0.57 \mathrm{mg} \cdot \mathrm{kg}^{-1}$, corresponding with the Se levels at the location A, whereas the soil Se level at location B was even lower. Gupta and Winter (1975) suggested that soil Se levels lower than $0.6 \mathrm{mg} \cdot \mathrm{kg}^{-1}$ were insufficient for optimum Se uptake by grazing animals. Thus, the soil Se levels at our investigated areas also seemed to be insufficient. The soil $\mathrm{pH}$ values varied from 5.2 to 5.7 , showing a slightly acidic reaction. Soil physicochemical parameters affect predominantly the Se speciation in the soils, as in alkaline soils are preferred selenates and, in contrast, in acidic soils the dominant Se forms are represented by selenites. However, selenates are suggested as the more plant-available Se species (Mikkeisen et al., 1987). Thus, lower mobility and plant-availability can be expected in our slightly acidic soils. The element portions extractable with $0.11 \mathrm{~mol} \cdot 1^{-1} \mathrm{CH}_{3} \mathrm{COOH}$ can be used for the estimation of the plant-available element portion in these soils (Sastre et al., 2004). The results show good mobility and potential plantavailability of Cd (up to $40 \%$ of the total content). Mobility of other elements was lower than $10 \%$ and dropped down in the order $\mathrm{Zn}>\mathrm{As} \geq \mathrm{Pb}>\mathrm{Cu}$. The lowest mobility was observed in the case of Se, which the extractable levels were under the detection limit of the used analytical technique regardless of the total soil Se content.

Se contents in all examined plant species were low in accordance with the low Se mobility in the soils (Table 3). Slightly higher Se levels were observed at location A, characterized by a higher total Se content. Moreover, slightly higher Se contents than in other analysed plant samples were found in Galium mollugo and Cirsium arvense. Kienzle and Möllmann (2009) determined very similar micronutrient contents in hay samples used for horse nutrition. In the case of Se, the levels were mostly under detection limit; among the detectable Se contents, the highest Se content was $0.021 \mathrm{mg} \cdot \mathrm{kg}^{-1}$ of 
dry matter. Vervuert et al. (2004) presented the Se concentration in roughage used for horse nutrition ranging $0.01-0.06 \mathrm{mg} \cdot \mathrm{kg}^{-1}$ of dry matter. Thus, the Se contents in the plant biomass did not differ from other locations in West and Middle Europe.

The contents of Se in roughage and oat grain itself are insufficient for horse nutrition, as previously observed by Ludvíková et al. (2005a). Meyer and Coenen (2002) stated that daily Se intake for adult horses should vary between 1.3 and $1.7 \mathrm{mg}$ per day, and thus, the daily intake of less than $0.35 \mathrm{mg}$ per day is insufficient. Montgomery et al. (2012) recommend the daily intake of even up to $4 \mathrm{mg}$ per day. In our case, the dominant portion of Se in the feeding dose is represented by Se-supplemented complementary feedstuffs such as pellets and muesli. Without these components, both feeding doses would have been Se-deficient. Moreover, variability in Se contents in feedstuffs collected at the same location did not allow to predict the Se status situation, and Se supplementation seems to be necessary in all cases.

Se and other micronutrient statuses of animals. Crisman et al. (1994) in USA randomly tested blood samples of 346 horses, and whole blood Se concentrations for the examined population ranged from $0.027 \mathrm{mg} \cdot 1^{-1}$ to $0.266 \mathrm{mg} \cdot 1^{-1}$. In Germany, plasma Se concentrations of 304 horses aged from 4 months to 29 years ranged from 0.016 to $0.291 \mathrm{mg} \cdot 1^{-1}$ (Vervuert et al. 2000). Contrarily, low heterogeneity of plasma Se concentrations was reported by Mihailovic et al. (1996) in Serbia. These authors compared Se plasma levels in horses kept at two farms on different feeding regimes. There were no significant differences in mean blood plasma Se concentrations in the horses $(0.073$ and $0.072 \mathrm{mg} \cdot 1^{-1}$, respectively). Horses with deficient Se serum level were reported by Pilarczyk et al. (2011) in different areas of Poland. The study showed that $\mathrm{Se}$ concentration in the serum of the horses ranged from 0.003 to $0.090 \mathrm{mg} \cdot 1^{-1}$, and no significant differences were found in Se concentrations between males and females. Similarly, Meyer et al. (1995) examined plasma Se concentrations in Northwest Germany and reported low values (on average $0.068 \mathrm{mg} \cdot 1^{-1}$ ), especially in horses kept on moor or sandy soils where the plant Se contents were the lowest. In our case, no extremely low Se blood levels were found at either location.

Pilarczyk et al. (2014) recently surveyed the serum Se concentrations in Polish Konik horses residing in the Odra Delta Nature Park (Poland). In over $95 \%$ of cases, serum Se concentration was below the optimal range, and none of the examined horse was deficient in this trace element. The authors speculated that the lack of Se deficiency in the examined animals suggests that the Polish Konik horses, as a specific semi-feral horse breed, have a natural ability to sufficiently utilize nutrients available in their life area. In contrast, Ludvíková et al. (2005a) reported the whole blood Se levels of the cultural horse breeds in the range between 0.05 and $0.238 \mathrm{mg} \cdot 1^{-1}$, and unambiguous relationships between low blood Se content and myopathy (Ludvíková et al., 2005b). In this context, differences in the Se status of racing, show jumping, endurance, dressage, hobby riding and breeding horses were observed, whereas levels of Se were found adequate in sport horses and deficient in recreational horses (Ludvíková et al., 2005a). A total number of samples in our experiment did not allow us to statistically assess the potential differences according to sex or age of the animals, but we can speculate that the sport and recreational horse groups differed most probably not because of their use but because of different Se contents in their diets.

Karren et al. (2010) observed higher serum Se contents $\left(0.253 \mathrm{mg} \cdot \mathrm{1}^{-1}\right)$ in mares fed grain mix than kept on pasture $\left(0.224 \mathrm{mg} \cdot \mathrm{l}^{-1}\right)$, due to three-fold higher Se concentrations in the grain mix than in pasture. A similar result was reported for their foals: foal serum Se contents at one month of age were $0.118 \mathrm{mg} \cdot 1^{-1}$ and $0.138 \mathrm{mg} \cdot 1^{-1}$ for mares fed forage or grain mix, respectively. The effect of Se contents in horse feedstuffs was also reported by Vervuert et al. (2004). The Se contents in the roughage were comparable, whereas the complementary feedings were significantly different. The Se content $0.24 \pm 0.2 \mathrm{mg} \cdot \mathrm{kg}^{-1}$ dry matter in the complement resulted in plasma Se concentration $0.066 \pm 0.047 \mathrm{mg} \cdot 1^{-1}$, and the plasma Se levels in animals fed complement with Se content $0.53 \pm 0.40 \mathrm{mg} \cdot \mathrm{kg}^{-1}$ was $0.117 \pm 0.082 \mathrm{mg} \cdot 1^{-1}$. Thus, Se supplementation of the diet is sufficient for the adequate Se status of the animals, and in our case resulted in effective elimination of the potential $\mathrm{Se}$ deficiency.

\section{Conclusions}

Low Se contents in soils resulted in low contents of Se in roughage produced at both investigated locations - no substantial differences were observed among the analysed plant species. The diet based only on the feedstuffs produced at the individual farms can lead to the Se deficiency in the animals. However, the Se levels in the blood of the investigated animals are comparable to horse blood Se levels determined across Europe due to the addition 
of Se-rich complementary feedstuffs. Therefore, in the Czech Republic the supplementation of the horse diet with $\mathrm{Se}$ is recommended to prevent the potential Se deficiency and subsequent health complications of animals.

\section{Acknowledgement}

Authors would like to thank the Czech Science Foundation (GACR) for financial support, project No. 13-04580S. Correction and improvement of language was provided by Proof-Reading-Service. com Ltd., Devonshire Business Centre, Works Road, Letchworth Garden City SG6 1GJ, UK.

\section{References}

Ali F., Lodhi L.A., Qureshi Z.I., Ahmad I., Hussain R., 2013. Serum mineral profile in various reproductive phases of mares. Pak. Vet. J. 33, 296-299

Bitterli C., Bañuelos G.S., Schulin R., 2010. Use of transfer factors to characterize uptake of selenium by plants. J. Geochem. Explor. 107, 206-216, https://doi.org/10.1016/j.gexplo.2010.09.009

Brummer M., Hayes S., Dawson K.A., Lawrence L.M., 2013. Measures of antioxidant status of the horse in response to selenium depletion and repletion. J. Anim. Sci. 91, 2158-2168, https://doi.org/10.2527/jas.2012-5794

Calamari L., Abeni F., Bertin G., 2010. Metabolic and hematological profiles in mature horses supplemented with different selenium sources and doses. J. Anim. Sci. 88, 650-659, https:// doi.org/10.2527/jas.2009-1855

Calamari L., Ferrari A., Bertin G., 2009. Effect of selenium source and dose on selenium status of mature horses. J. Anim. Sci. 87 167-178, https://doi.org/10.2527/jas.2007-0746

Caple I.W., Edwards S.J.A., Forsyth W.M., Whiteley P., Selth R.H., Fulton L.J., 1978. Blood glutathione peroxidase activity in horses in relation to muscular dystrophy and selenium nutrition. Aust. Vet. J. 54, 57-60, https://doi.org/10.1111/j.1751-0813.1978. tb00343.x

Coenen M., Landes E., Assmann G., 1998. Selenium toxicosis in the horse - case report. J. Anim. Physiol. Anim. Nutr. 80, 153157, https://doi.org/10.1111/j.1439-0396.1998.tb00518.x

Crisman M.V., Carmel D.K., Lessard P., Ley W.B., 1994. A survey of whole blood selenium concentrations of horses in Virginia and Maryland. J. Equine Vet. Sci. 14, 256-261, https://doi. org/10.1016/S0737-0806(06)81950-7

Czech Ministry of the Environment, 1994. Public notice No. 13/1994, regulating some details concerning the preservation of agricultural lands available. Prague (CZE)

Davies Z., 2009. Introduction to Horse Nutrition. Wiley-Blackwell. Chichester (UK)

de Moffarts B., Kirschvink N., Art T., Pincemail J., Lekeux P., 2005. Effect of oral antioxidant supplementation on blood antioxidant status in trained thoroughbred horses. Vet. J. 169, 65-74, https://doi.org/10.1016/j.tvjl.2003.12.012

Detlef E., Hertsch B., Wollgienhahn D., 1995. Selenium intoxication in competition horses resulting on nutrition. Pferdeheilkunde $11,273-281$
Gordon M.E., Edwards M.S., Sweeney C.R., Jerina M.L., 2013. Effects of added chelated trace minerals, organic selenium, yeast culture, direct-fed microbials, and Yucca schidigera extract in horses. Part I: Blood nutrient concentration and digestibility. J. Anim. Sci. 91, 3899-3908, https://doi.org/10.2527/ jas.2013-6122

Gupta U.C., Gupta S.C., 2000. Selenium in soils and crops, its deficiencies in livestock and humans: Implications for management. Commun. Soil Sci. Plant Anal. 31, 1791-1807, https:// doi.org/10.1080/00103620009370538

Gupta U.C., Winter K.A., 1975. Selenium content of soils and crops and effects of lime and sulfur on plant selenium. Can. J. Soil Sci. 55, 161-166, https://doi.org/10.4141/cjss75-023

Haggett E., Magdesian K.G., Maas J., Puschner B., Higgins J., Fiack C., 2010. Whole blood selenium concentrations in endurance horses. Vet. J. 186, 192-196, https://doi.org/10.1016/j. tvjl.2009.07.017

Karren B.J., Thorson J.F., Cavinder C.A., Hammer C.J., Coverdale J.A., 2010. Effect of selenium supplementation and plane of nutrition on mares and their foals: Selenium concentrations and glutathione peroxidase. J. Anim. Sci. 88, 991997, https://doi.org/10.2527/jas.2008-1743

Kienzle E., Möllmann F., 2009. Trace element analyses in hay for horses - analyse once, "guestimate" in the next years. Tierärztl. Prax. 37, 242-246

Ludviková E., Jahn P., Pavlata L., Vyskočil M., 2005b. Selenium and vitamin $E$ status correlated with myopathies of horses reared in farms in the Czech Republic. Acta Vet. Brno 74, 377-384, https://doi.org/10.2754/avb200574030377

Ludvíková E., Pavlata L., Vyskočil M., Jahn P., 2005a. Selenium status of horses in the Czech Republic. Acta Vet. Brno 74, 369-375, https://doi.org/10.2754/avb200574030369

Masters D.G., Judson G.J., White C.L., Lee J., Grace N.D., 1999. Current issues in trace element nutrition of grazing livestock in Australia and New Zealand. Aust. J. Agric. Res. 50, 1341-1364, https://doi.org/10.1071/AR99035

Meloun M., Militký J., 2004. Statistical Analysis of the Experimental Data. (in Czech) Academia, Praha (Czech Republic)

Meyer H., Coenen M., 2002. Pferdefütterung (in German). Parey Buchverlag, Berlin (Germany)

Meyer H., Zentek J., Heikens A., Struck S., 1995. Investigations on the Se-supply of horses in North-West Germany. Pferdeheilkunde 11,315

Mihailovic M., llic V., Lindberg P., 1996. Blood glutathione peroxidase activity, selenium and vitamin $\mathrm{E}$ concentrations of race horses in Serbia. Acta Vet. Beograd 46, 27-32

Mikkeisen R.L., Haghnia G.H., Page A.L., 1987. Effects of pH and selenium oxidation state on the selenium accumulation and yield of alfalfa. J. Plant Nutr. 10, 937-950, https://doi. org/10.1080/01904168709363621

Minini R.A.B., Laposy C.B., Neto H.B., Melchert A., Giuffrida R., De Rossi H., do Valle H.F.D., 2013. Serum concentration of iron, copper, zinc and manganese in Pure-bred Lusitano horses, before and after exercise. Pesqui. Vet. Bras. 33, 10451048, https://doi.org/10.1590/S0100-736X2013000800016

Montgomery J.B., Wichtel J.J., Wichtel M.G., McNiven M.A., McClure J.T., Markham F., Horohov D.W., 2012. The effects of selenium source on measures of selenium status of mares and selenium status and immune function of their foals. J. Equine Vet. Sci. 32, 352-359, https://doi.org/10.1016/j. jevs.2011.12.003

Müller A., Bertram A., Moschos A., 2012. Differences in the selenium supply of horses across Europe. Tierärztl. Prax. 40, 157-166 
Novozamsky J., Lexmond Th.M., Houba V.J.G., 1993. A single extraction procedure of soil for evaluation of uptake of some heavy metals in plants. Int. J. Environ. Anal. Chem. 51, 47-58, https://doi.org/10.1080/03067319308027610

Pilarczyk B., Tomza-Marciniak A., Stankiewicz T., Błaszczyk B., Gaczarzewicz D., Smugała M., Udała J., Tylkowska A., Kuba J., Cieśla A., 2014. Serum selenium concentration and glutathione peroxidase activity and selenium content in testes of Polish Konik horses from selenium-deficient area in NorthWestern Poland. Pol. J. Vet. Sci. 17, 165-167, https://doi. org/10.2478/pjvs-2014-0022

Pilarczyk B., Udała J., Stankiewicz T., Hendzel D., Tylkowska A., Vovk S., 2011. Evaluation of serum selenium concentrations in horses from the area of Poland. Tieräerztl. Umschau 66, 163-165

Quevauviller P., Ure A., Muntau H., Griepink B., 1993. Improvement of analytical measurements within the BCR-programme: Single and sequential extraction procedures applied to soil and sediment analysis. Int. J. Environ. Anal. Chem. 51, 129-134, https://doi.org/10.1080/03067319308027618

Rayman M., 2008. Food-chain selenium and human health: emphasis on intake. Br. J. Nutr. 100, 254-268, https://doi.org/10.1017/ S0007114508939830

Richardson S.M., Siciliano P.D., Engle T.E., Larson C.K., Ward T.L., 2006. Effect of selenium supplementation and source on the selenium status of horses. J. Anim. Sci. 84, 1742-1748, https://doi.org/10.2527/jas.2005-413

Sastre J., Hernández E., Rodríguez R., Alcobé X., Vidal M., Rauret G., 2004. Use of sorption and extraction tests to predict the dynamics of the interaction of trace elements in agricultural soils contaminated by a mine tailing accident. Sci. Total Environ. 329, 261-281, https://doi.org/10.1016/j.scitotenv.2004.03.012

Streeter R.M., Divers T.J., Mittel L., Korn A.E., Wakshlag J.J., 2012. Selenium deficiency associations with gender, breed, serum vitamin $\mathrm{E}$ and creatine kinase, clinical signs and diagnoses in horses of different age groups: A retrospective examination 1996-2011. Equine Vet. J. 44, Suppl. S43, 31-35, https://doi. org/10.1111/j.2042-3306.2012.00643.x
Swecker W.S. Jr., Eversole D.E., Thatcher C.D., Blodgett D.J., 1991 Selenium supplementation of gestating beef-cows on selenium-deficient pastures. Agri-Practice 12, 25-30

Swecker W.S. Jr., Thatcher C.D., Eversole D.E., Blodgett D.J., Schurig G.G., 1995. Effect of selenium supplementation on colostral IgG concentration in cows grazing selenium-deficient pastures and on postsuckle serum $\lg G$ concentration in their calves. Am. J. Vet. Res. 56, 450-453

Thorson J.F., Karren B.J., Bauer M.L., Cavinder C.A., Coverdale J.A., Hammer C.J., 2010. Effect of selenium supplementation and plane of nutrition on mares and their foals: Foaling data. J. Anim. Sci. 88, 982-990, https://doi.org/10.2527/jas.20081646

Vervuert I., Coenen M., Braun S., 2004. Feeding management of Icelandic horses in Iceland and after importation in Germany with emphasis on selenium supply, $1^{\text {st }}$ communication. Pferdeheilkunde 20, 2329

Vervuert I., Coenen M., Höltershinken M., Venner M., Rust P., 2000. Current findings for the assessment of the selenium supply in the horses (in German) Tierärztl. Prax. 28, 172-177

Wichert B., Frank T., Kienzle E., 2002. Zinc, copper and selenium intake and status of horses in Bavaria. J. Nutr. 132, 1776S-1777S

Youssef M.A., El-khodery S.A., Ibrahim H.M.M., 2012. Antioxidant trace elements in serum of draft horses with acute and chronic lower airway disease. Biol. Trace Elem. Res. 150, 123-129, https://doi.org/10.1007/s12011-012-9471-0

Yur F., Dede S., Deger Y., Kilicalp D., 2008. Effects of vitamin E and selenium on serum trace and major elements in horses. Biol. Trace Elem. Res. 125, 223-228, https://doi.org/10.1007/ s12011-008-8109-8 